\title{
VICTORIA \\ NATURAL RADIOCARBON MEASUREMENTS I
}

\author{
ANNE BERMINGHAM
}

Institute of Applied Science of Victoria, Melbourne

This list contains a selection of results of measurements made since September, 1963. Until the end of 1962, the stability of equipment performance was unsatisfactory and, when the author assumed responsibility for the operation of the laboratory in 1963, several dates that had been published (Focken, 1960, 1962, and private commun.) were withdrawn. The performance and operation of the equipment were re-assessed and improved during 1963 and routine dating was begun towards the end of the year.

All determinations have been made with a proportional counter, ca. $31 / 2 \mathrm{~L}$, which is shielded by $1 \mathrm{in}$. mercury, a double coincidence ring and an 8 in. steel shield. Carbon dioxide is used as the filling gas, final purification being made by absorption on lime.

The electronic system is duplicated after the preamplification stage; a single channel analyzer is paralleled by a four channel analyzer which can be used to correct for radon impurity. A system of overall gain stabilization devised by R. D. Carman (1961) uses variations in the coincidence pulse amplitude distribution in the four channel analyzer to supply an automatic correction voltage to the counter. All recorded count rates are monitored at 50 or 100 min intervals and subsequently analyzed. Neutron monitoring equipment runs in conjunction with the dating equipment.

Changes in anticoincidence count rates with barometric pressure have not been detected; analysis of background and standard count rates gives variations close to statistical expectation over long periods.

Age calculations are based on a modern reference activity of $95 \%$ NBS oxalic-acid standard and the value 5568 yr for the half-life of $\mathrm{C}^{14}$. Results are expressed in years before A.D. 1950. The statistical error quoted $(1 \sigma)$ is derived solely from the counting statistics and the uncertainty in the half-life figure is not included. Minimum ages for samples indistinguishable from background are calculated on an activity of $3 \sigma$ above background.

Pretreatment of samples with hydrochloric acid and sodium hydroxide is routine, but this procedure has been modified where sample size precluded an alkali leaching.

Sample descriptions are based on information supplied with the samples, or have been provided by the persons submitting the samples.

\section{ACKNOWLEDGMENTS}

The work reported here has been carried out within the Institute of Applied Science of Victoria and is published with the permission of its Trustees and Director. The laboratory is financed by the State Govern- 
ment of Victoria; additional support from the Australian Institute of Nuclear Science and Engineering is gratefully acknowledged.

Measurements of $\mathrm{C}^{13} / \mathrm{C}^{12}$ ratios of standards were made by the Institute of Nuclear Sciences, Department of Scientific and Industrial Research, New Zealand, through the kind co-operation of the Director, Mr. T. A. Rafter, and the staff. Special thanks are due to the laboratories which supplied check samples, and grateful acknowledgment is made to submitters of samples who assisted with descriptions.

The author is particularly indebted to Mr. David Turner, who joined the laboratory in June 1964, for his excellent assistance.

\section{SAMPLE DESCRIPTIONS}

I. GEOLOGIC SAMPLES

A. New South Wales

\section{Riverine plain series, New South Wales}

Transported wood samples in alluvium; coll. by Trevor LangfordSmith in continuation of a long-term study of geomorphic history of New South Wales sector of Australia's inland riverine plains (LangfordSmith, 1960, 1962) for which eight dates (Murrumbidgee Plain series) were reported in Yale VIII. Coll. Sept 1960 and subm. by T. LangfordSmith, Univ. of Sydney.

\section{V-46. Learmonth Well}

A.D. 1490

$160 \pm 105$

From relic of former stream 6 to 24 in. below present surface of stream bed, $17 \mathrm{mi} \mathrm{W}$ of Griffith, New South Wales (34 $15^{\prime} \mathrm{S}$ Lat, $145^{\circ}$ $45^{\prime}$ E Long).

\section{V-47. Moppin}

$2265 \pm 120$

From 12 in. below surface of bed of former stream, $20 \mathrm{mi} \mathrm{N}$ of Moree, New South Wales (29 $20^{\prime} \mathrm{S}$ Lat, $149^{\circ} 40^{\prime} \mathrm{E}$ Long). Comment (T.L.-S.): V-46 is part of former Murrumbidgee system which, so far, has given a clustering of dates into an old group, 11,000 yr or older, and a younger group, $4700 \mathrm{yr}$ or younger. Previous date for this system of $300 \pm 70$ (Y-869, Yale VIII) was rejected as possibly part of a modern root, but this date of $460 \pm 105$ suggests possibility of some stream discharge at about this time. V-47 is from series of former streams some 400 mi NW of V-46, but still part of same riverine plain series. Age is close to $2480 \pm 80$ (Y-862, Yale VIII) obtained for wood from a stream near $\mathrm{V}$-46. Further field work and dating necessary before firm conclusions can be reached as to episodes of stream flow in these alluvial traces.

\section{V-7. Gooloogong, Lachlan Valley, New South Wales}

Wood, probably Eucalyptus resinifera (id. by R. K. Bamber), from depth of $86 \mathrm{ft}$ in Bore 12437 (33 $38^{\prime} 20^{\prime \prime} \mathrm{S}$ Lat, 148 $31^{\prime} 30^{\prime \prime} \mathrm{E}$ Long), Portion 56, Parish of Gooloogong, County of Forbes; ca. 3 mi upstream 
of village of Gooloogong, Lachlan River Valley, New South Wales. See Williamson (1964) for discussion of groundwater investigations in area; geology of area is also described by Williamson (1961). Coll. June 1960 by B. McDonald; subm. by W. H. Williamson, Water Conservation and Irrigation Comm., N.S.W. Comment (W.H.W.): date confirmed that age of sediments being test-bored was beyond radiocarbon dating limits; subsequent geological and palynological information indicates Pleistocene age.

\section{5 в.c.}

Wood from outer section of root of Eucalyptus gummifera (id. by H. D. Ingle), part of tree stump taken from position of growth $48 \mathrm{ft}$ below sealevel. Stump was found during excavation of Captain Cook graving dock (33 52' $0^{\prime \prime} \mathrm{S}$ Lat, $151^{\circ} 13^{\prime} 40^{\prime \prime} \mathrm{E}$ Long), Sydney, New South Wales, and was covered by $6 \mathrm{ft}$ of sediment. Sample has also been dated at $8360 \pm 110$ yr (NZ-lab. no. not available, ref. no. R1219/1, private commun.). Coll. ca. 1940 by Forestry Comm. of New South Wales; subm. by Quaternary Strandlines Comm., ANZAAS, per E. D. Gill. Comment (E.D.G.): as specimen was in position of growth, sea at that time must have been lower by at least $48 \mathrm{ft}$ plus depth of roots, estimated (from photograph) at $10 \mathrm{ft}$.

\section{B. Victoria}

\section{V-23. Murmungee 38, Ovens Valley, Victoria}

Eucalyptus camaldulensis (id. by J. Douglas) from $95 \mathrm{ft}$ below present Ovens Valley surface, in black carbonaceous clay horizon of alluviumfilled valley of Ovens River, $31 / 2 \mathrm{mi} \mathrm{N}$ of Myrtleford, Victoria $\left(36^{\circ} 32^{\prime}\right.$ S Lat, $146^{\circ} 41^{\prime}$ E Long). Coll. Oct 1961 and subm. by B. R. Thompson, Mines Dept., Victoria. Comment (B.R.T.): date supports conclusion that alluvial material in these valleys is considerably older than Recent period (Thompson, 1965).

\section{Ford's Creek series, Mansfield, Victoria}

Wood samples from trunks of red gum, probably Eucalyptus camaldulensis, in exposed banks of two eroded creeks; soil layers are thought to be latest pre-white settlement deposits in Mansfield area. Collection sites were on Graves and Kelleher properties $\left(37^{\circ} 6^{\prime} \mathrm{S}\right.$ Lat, $146^{\circ} 71 / 2^{\prime} \mathrm{E}$ Long), 21/2 mi E of Mansfield, Victoria. Coll. Dec 1962 and subm. by A. Rundle, Soil Conserv. Authority, Victoria.

\section{V-38. Graves property}

$290 \pm 50$

Wood near base of soil profile in exposed bank of eroded creek, ca. $200 \mathrm{yd} \mathrm{N}$ of Mt. Buller road. 


\section{V-37. Kelleher property}

Wood near base of soil profile in exposed bank of eroded creek, ca. 250 yd S of Mt. Buller road. Comment (K. Rowe, Soil Conserv. Authority): V-37 was thought to be younger than $\mathrm{K}_{3}$ in Butler's cycle (Butler, 1959); V-38 was tentatively regarded as being of $\mathrm{K}_{1}$ age. These tentative $\mathrm{K}$-cycle designations were derived from a study of relative relationships of local soil layers by stratigraphic and pedogenetic means, particularly in terrace sequences. Samples were dated to provide a time marker in recent soil history and, by comparison with other dates for soil material, principally those for Nowra, New South Wales (NZ-198, NZ-199, NZ-200, NZ-201, New Zealand I-V; Walker, 1962), to help demonstrate extent of processes resulting in formation of the layers. On basis of dates for Nowra area, both logs are no older than $\mathbf{K}_{1}$.

\section{ARCHAEOLOGIC SAMPLES}

\section{A. New South Wales}

\section{Seelands series, Clarence Valley, New South Wales}

Charcoal samples from rock shelter at Seelands $\left(29^{\circ} 35^{\prime} 20^{\prime \prime} \mathrm{S}\right.$ Lat, $152^{\circ} 54^{\prime} 30^{\prime \prime}$ E Long), $12 \mathrm{mi} \mathrm{NW}$ of Grafton, Clarence Valley, New South Wales. Shelter is on S bank of Clarence River and is one of series in low sandstone cliff whose rock wall bears simple linear engravings. Coll. Aug 1960 (V-24, V-25, V-26, V-27) and June 1961 (V-10, V-11) and subm. by Isabel McBryde, Univ. of New England.

\section{V-24. Seelands, Trench 2(f), V}

$4040 \pm 65$

2090 B.c.

Charcoal from Trench 2, Zone (f), Layer V, ca. 30 in. below surface of deposit in rock shelter. One of lowest levels of deposit within shelter; stratigraphically below V-10, V-26, V-25. Comment (I.McB.): dates an industry of predominantly uniface pebble tools and the first appearance of backed blade tools on this site.

\section{V-25. Seelands, Trench 2(c), III}

$870 \pm 80$

Charcoal from Zone (c), Layer III, 12 in. below surface of deposit in rock shelter. Implements included blade and uniface pebble tools as well as bone artifacts; a level rich in animal bone, stone, and bone artifacts. Stratigraphically below V-10 and V-26.

\section{V-26. Seelands, Trench 2(d), II}

$350 \pm 60$

Charcoal from Zone (d), Layer II, 6 to 9 in. below surface of deposit in shelter; same stratigraphic level as V-10. Stone artifacts from this level, and Level III below, included uniface pebble tools and blade tools, associated with bone implements. 
Charcoal from Trench 1, Zone (c), Layer IV, 18 to 24 in. below surface of deposit outside rock shelter and $20 \mathrm{ft}$ NW of Trench 2. Associated with large primary flakes and uniface pebble tools; no blade tools.

V-10. Seelands, Trench 5(d), II

$625 \pm 85$

Charcoal from Zone (d), Layer II, 9 to 12 in. below surface of deposit in rock shelter. Stratigraphically the same level as V-26; stone artifacts included uniface pebble tools and blade tools, including geometric microliths, associated with bone implements. Comment: date for this sample published by I. McBryde (1961, 1962, 1963) was withdrawn.

\section{V-11. Seelands, Trench $5\left(\mathrm{e}^{3}\right)$, IIIA}

$2850 \pm 50$

Charcoal from Zone $\left(\mathrm{e}^{3}\right)$, Layer IIIA, 18 in. below present surface outside limits of shelter overhang. Comment: date for this sample published by I. McBryde (1961, 1962, 1963) was withdrawn. Comment (I.McB): this level of dark black soil contained few animal bones and no bone artifacts, but was rich in stone artifacts, with blade tools (including Bondi points and geometric microliths) and uniface pebble tools which, in this level, are in the highest proportion for any level assemblage at this site. First evidence for edge-ground artifacts at this site (a broken axe-head) was stratified below sample. Charcoal sample taken from this level, but further down talus slope to NW, gave date of $1210 \pm 30$ (GaK-370, Gakushuin IV) which is markedly more recent, but in accord with stratigraphic position of this level below Levels II and III of Trenches 2 and 5 (V-10, V-26, V-25). It suggests that this level represents a long period in history of site (McBryde, 1965).

General Comment (I.McB.): this site was the first excavated in northeastern New South Wales and this, with the long period of occupation represented by its dated levels, makes it of considerable interest for establishing local regional sequence of cultural change, and for comparison with that established for eastern New South Wales in Sydney area (McCarthy, 1961, 1964; Mulvaney, 1961; Megaw, 1965).

\section{Chambigne series, Clarence Valley, New South Wales}

Small rock shelter with shallow occupation deposit at Chambigne, SW of Grafton, Clarence Valley, New South Wales $\left(29^{\circ} 47^{\prime} \mathrm{S}\right.$ Lat, $152^{\circ}$ $46^{\prime}$ E Long). Art consists of a group of white hand stencils on rear wall of shelter. Coll. May 1962 and subm. by I. McBryde.

\section{V-39. Chambigne, Trench 2(a), I}

$$
1350 \pm 75
$$

\section{A.D. 600}

Charcoal from Layer I, 3 in. below surface of shallow cave deposit in shelter; associated with animal bones, shell, and stone implements, chiefly use-polished pieces, geometric microliths and flake fabricators. 
V-40. Chambigne, Trench $3(d)$, I

A.D. 310

Charcoal from Zone (d), Layer I, 21 to 30 in. below surface of deposit of talus slope outside rock shelter and beneath a rock fall. Layer rich in cultural material; implements include pebble tools and the greatest number of geometric microliths from site. Comment (I.McB.): cultural material of site, with association of uniface pebble tools and blade tools (especially geometric microliths), shows close relationship to that of Seelands rock shelter (this list); here the blade tools form dominant element.

\section{Jacky's Creek series, Clarence Valley, New South Wales}

Rock shelter with occupation deposit at Jacky's Creek, $14 \mathrm{mi}$ SW of

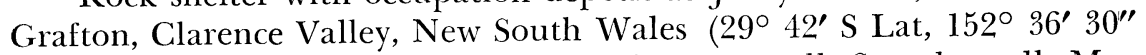
E Long). Red ocher and charcoal drawings on wall. Samples coll. May and June 1962 and subm. by I. McBryde.

\section{V-41. Jacky's Creek, Trench 1(b), I}

$1310 \pm 70$

Charcoal from Zone (b), Layer I, 5 to 6 in. below surface of deposit in rock shelter. Artifacts from level include bone points, stone usepolished edges, and part of a ground-edged axe.

\section{V-42. Jacky's Creek, Trench 1(a), III}

$1465 \pm 75$

Charcoal from Layer III, 15 in. below surface of deposit in rock shelter, stratigraphically below level from which V-41 was collected. Level poor in artifact content.

\section{V-43. Jacky's Creek, Trench 1(e), IIA}

$1225 \pm 70$

Charcoal from Zone (e), Level IIA, 6 to 9 in. below surface of deposit in rock shelter at its entrance where stratigraphic pattern changes, probably due to redeposition. Level was richest in cultural material; implements included uniface pebble tools, broken ground-edged axes, and use-polished pieces. A few blade tools were found, but no bone artifacts.

\section{V-44. Jacky's Creek, Trench 3, IIA}

$1285 \pm 90$

Charcoal from Layer IIA, Trench 3 (an extension of Trench 1), 9 in. below surface of deposit in rock shelter. From same area and stratigraphic level as V-43. Comment (I.McB.): date agrees well with V-43 and dates same cultural material.

\section{V-45. Jacky's Creek, Trench 2(d), I}

$585 \pm 90$

Charcoal from Zone (d), Layer I, 6 in. below surface of deposit in rock shelter. First occupation layer encountered; thought to correspond to Layer I in Trench 1 (V-41). Comment (I.McB.): date is much more 
recent than V-41 from same level, and may represent later intrusive evidence of occupation. There were some signs of disturbance in this zone. Cultural material was similar to that for V-41, but sample was directly associated with small piece of sandstone bearing marks in red ocher and may, therefore, throw light on age of red ocher art of site.

General Comment (I.McB.): evidence from this site supplements and confirms that of Seelands and Chambigne for chronology and associations of various stone industries.

\section{Capertee Valley series, New South Wales}

Charcoal samples from two rock shelters, Site 3 and Noola, in the Capertee Valley, New South Wales. Site 3 is on $\mathrm{S}$ bank of Capertee River, $21 / 2 \mathrm{mi} \mathrm{E}$ of junction with Running Stream and $4 \mathrm{mi} \mathrm{NE}$ of Glen Davis (33 $7^{\prime} \mathrm{S}$ Lat, $150^{\circ} 20^{\prime} \mathrm{E}$ Long). It has been described fully by F. D. McCarthy (1964). Noola rock shelter, Noola Station, $20 \mathrm{mi}$ NW of Site 3 shelter, has been described by N. B. Tindale in a preliminary report (Tindale, 1961). Date of 11,600 \pm 400 (GaK-334, Gakushuin III) was previously obtained for finely dispersed charcoal at depth of $121 \mathrm{in}$. Comment: this date and $\mathrm{V}-35$ (this list) are incompatible with gradual deposition from 121 to 74 in. levels during long occupation of narrow shelter (ca. $2 \mathrm{ft}$ wide).

\section{V-33. Site 3, 8 to 10 in.}

$2865 \pm 60$

From 8 to $10 \mathrm{in}$. below surface; associated with Bondaian implements. Coll. Dec 1960 and subm. by F. D. McCarthy, Australian Mus. Comment (F.D.McG.): dates upper period of Bondaian phase of Eastern Regional Sequence which consists, in this site, of ground-edge axes, knapped scrapers, knives, burins, Bondi points, geometric microliths, flake fabricators, gum hafting, elouera adze flake. Bones of living species of lizards and mammals present. Bondaian is middle phase of above sequence.

\section{V-34. Site 3, 41 to 43 in.}

$$
3625 \pm 70
$$

From I ayer 6,41 to 43 in. below by F. D. Mec 1960 and subm. tian culture tian culture. Uniface pebble implements in Layers 7 to 8 (49 to 72 in. below surface).

\section{V-18. Site 3, 68 to 76 in.}

$7360 \pm 125$ 5410 B.C.

From Layers 8 to 9,68 to 76 in. below surface; associated with Capertian (oldest) phase of Eastern Regional Sequence. Coll. May 1961 by F. D. McCarthy and Donald Currie; subm. by Donald Currie. Comment (F. D. McC.): sample from fireplace at bottom of deposit associated with large primary flake and blade implements with dentated edges. No bone material present. 
V-35. Noola, 74 in.

$12,550 \pm 185$

10,600 B.c.

Charcoal at depth of 74 in.; top layer of a hearth resting on a prepared floor of rounded stones. A large and characteristic implement of nosed-graver type was found in ashes. Coll. May 1961 and subm. by N. B. Tindale, South Australian Mus. Comment (N.B.T.): dates a Tartangan horizon.

V-36. Noola, 25 in.

$5320 \pm 90$

3370 B.C.

Charcoal forming single hearth at depth of 25 in., sealed below large rock slab. Coll. May 1961 and subm. by N. B. Tindale. Comment (N.B.T.): dates end of relatively long sterile period after Tartangan hearth (V-35), and beginning of a more intense Mudukian occupation of upper layers.

General Comment: terminology for cultural sequence in descriptions of these two sites differs due to differing interpretations of Australian prehistory by F. D. McCarthy $(1948,1949,1958,1963)$ and N. B. Tindale $(1957)$.

V-49. Mt. Grenfell Station, New South Wales

A.D. 1750

$200 \pm 65$

Charcoal from depth of 7 to 8 in. in rock shelter, Mt. Grenfell Station, $30 \mathrm{mi}$ NW of Cobar, New South Wales $\left(31^{\circ} 30^{\prime} \mathrm{S}\right.$ Lat, $145^{\circ} 35^{\prime} \mathrm{E}$ Long). Shelter is one of seven containing an elaborate series of paintings; deposit yielded implements characteristic of lower Murray River deposits excavated at Fromm's Landing (Mulvaney, 1960) and Devon Downs (Hale and Tindale, 1930). Implement range comprised high proportion of tula slugs, a few scrapers and tula chisels, fragments of millstones and ground edge axes, and represents most recent and modern phase of Tula Inland Sequence in central western New South Wales. Coll. Oct 1960 and subm. by F. D. McCarthy. Project was financed by Nuffield Foundation of Australia.

\section{V-50. Wuttagoona Station, New South Wales}

A.D. 1640

$310 \pm 75$

Gharcoal from depth of 8 to $10 \mathrm{in}$. in rock shelter at Wuttagoona Station, $30 \mathrm{mi}$ NW of Cobar, New South Wales $\left(31^{\circ} 20^{\prime} \mathrm{S} \mathrm{Lat,} 145^{\circ} 50^{\prime} \mathrm{E}\right.$ Long). Shelter lies $10 \mathrm{mi} \mathrm{NE}$ of Mt. Grenfell Station shelter (this list, $\mathrm{V}-49$ ) and contains similar implements and paintings. Coll. Oct 1960 and subm. by F. D. McGarthy. Project was also financed by Nuffield Foundation of Australia.

\section{B. Queensland}

\section{V-22. Polka Point, Stradbroke Island,} Queensland

$765 \pm 45$

Charcoal from shell midden at Polka Point, $1 \mathrm{mi} \mathrm{N}$ of Dunwich,

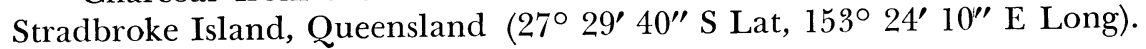


From Layer 4, ca. $1 \mathrm{ft}$ below existing surface (Univ. of Qld. Anthrop. Mus. cat. no.: Brisb/1/L20/4/153). Sample coll. Aug 1961 by J. Golson and D. J. Tugby; subm. by D. J. Tugby, Univ. of Queensland.

\section{Northern Territory}

\section{Macassar Well series, Milingimbi Island, Northern Territory}

Shell midden at Macassar Well Mound, $500 \mathrm{yd} \mathrm{W}$ of Milingimbi Methodist Mission, Arnhem Land, Northern Territory (12 $6^{\prime} \mathrm{S}$ Lat, $134^{\circ} 51^{\prime} \mathrm{E}$ Long). Well and its surrounding trees (Tamarindus indicus) are traditionally ascribed to Macassan trepang fishers. Site was excavated by W. L. Warner in 1927 (Warner, 1937) and, in 1948, by F. D. McCarthy and F. M. Setzler (McCarthy and Setzler, 1960). Samples were taken from an eroded section between Warner's trench and Trench B of McCarthy and Setzler. Coll. Aug 1965 and subm. by D. J. Mulvaney, Australian Nat. Univ.

\section{V.59. Macassar Well 1}

Charcoal, Sample 1, from $5 \mathrm{ft} 8$ in. to $5 \mathrm{ft} 10$ in. below surface of shell mound.

\section{V.60. Macassar Well 2}

$2445 \pm 80$ 495 B.c.

Charcoal, Sample 2, from base of shell mound, $5 \mathrm{ft} 10$ in. to $6 \mathrm{ft} 2$ in. below surface. Dates earliest occupation of site.

General Comment (D.J.M.): Macassan contact is inferred to belong to the past few centuries, but it is evident from these dates that original occupation around well was much earlier than this contact period. The traditional name is, therefore, a late attribution. No Macassan-type objects have, so far, been found in excavations at the site.

\section{Garrki series, Milingimbi Island, Northern Territory}

Garrki shell mound is ca. $11 / 2 \mathrm{mi} \mathrm{SW}$ of Milingimbi Methodist Mission, Arnhem Land, Northern Territory (12 $7^{\prime} \mathrm{S}$ Lat, $134^{\circ} 50^{\prime} \mathrm{E}$ Long). Mound, now partly destroyed, is one of largest known shell mounds (diam $70 \mathrm{ft}$, present height $13 \mathrm{ft}$, but probably once over $20 \mathrm{ft}$ ) in Australia. Coll. Aug 1965 and subm. by D. J. Mulvaney.

\section{V.62. Garrki 2}

$1170 \pm 85$ mound.

Charcoal, Sample 2, from $7 \mathrm{ft} 6$ in. below existing surface of shell

\section{V-61. Garrki 1}

$$
\begin{array}{r}
1305 \\
\text { A.D. } 645
\end{array}
$$
surface.

Charcoal, Sample 1, from base of shell mound, $13 \mathrm{ft}$ below existing General Comment (D.J.M.) : no evidence is available on rate of accumulation on Australian shell middens. At Garrki mound shells are loosely 
piled; at Macassar Well mound they are compacted. Garrki samples were collected near perimeter; interior has been entirely removed and it was impossible to make observations on processes of stratigraphic accumulation.

\section{India}

\section{Ahar mound series, Rajasthan, India}

Mound of Ahar, situated $220 \mathrm{yd} \mathrm{E}$ of Ahar village and ca. $2 \mathrm{mi} \mathrm{E}$ of Udaipur city, Rajasthan, India (24 $40^{\prime} \mathrm{N}$ Lat, $73^{\circ} 50^{\prime} \mathrm{E}$ Long), is a "tell" consisting of some 11 acres of occupational debris rising to maximum height of ca. $45 \mathrm{ft}$ above surrounding fields. It lies on NE bank of Ahar River and is traversed by two modern roads. Since excavations there in 1955 by Shri R. Agrawala (Sankalia, 1962), mound has been known to be center of a Chalcolithic culture rich in wares of black-and-red family found at Harappan Lothal (Rao, 1959-1960) and elsewhere. It is now known that the particular ceramic complex identified at Ahar in the 1961-1962 excavations is peculiar to basin of Banas River, of which the Ahar River is a tributary. The dating range of black-and-red ware is an important desideratum because of its probable diffusion from the Banas into adjacent cultures (e.g., in Deccan and Gujarat). Ahar (Aghātapura) is first mentioned in historical literature ca. A.D. 900 (Culican, 1961-1962) when it was almost extinct.

The 1961-1962 excavations were undertaken as a joint project of Deccan College of Postgraduate Research, Poona, Rajasthan Government, and Univ. of Melbourne. Preliminary report has been published by Sankalia (1961-1962); full report is in preparation. Charcoal samples were taken from two parts of the mound: (1) Trenches Y, Z and (2) Trenches H, J, K which lie 35 yd SE of Y, Z. Datum line 00 was used for all parts of the mound, the datum point being an erect stone on highest part of mound. Dates previously obtained for Ahar mound (TF-31, TF-32, TF-34, TF-37, Tata I) indicated that Chalcolithic occupation there was largely in earlier part of second millenium в.c. (Lal, 19621963).

\section{V-54. Ahar mound, Trench $Z$}

$3835 \pm 95$ 1885 B.C.

Charcoal from hearth below shallow pottery dish in Layer $9(37 \mathrm{ft}$ below datum). Dish was associated with a jar containing copper sheeting and with piriform vessels of an unusual fabric, found also in Trench $\mathrm{H}$. Coll. Feb 1962 by C. E. V. Nixon and W. Culican; subm. by W. Culican, Dept. of Semitic Studies, Univ. of Melbourne.

\section{V-56. Ahar mound, Trench $Y$}

Charcoal from hearth in Layer 8, ca. $37 \mathrm{ft}$ below datum; associated with "tan wares", a phase of black-and-red pottery in which a light brown ocherous wash was applied to the surface. It is possible that this phase 
of "tan wares" was relatively restricted. Coll. Jan 1962 and subm. by W. Culican.

\section{V-57. Ahar mound, Trench $H$}

Charcoal from Layer 7, $37 \mathrm{ft}$ below datum; a particularly rich ceramic horizon associated with tan-slipped-and-burnished pottery. Coll. Feb 1962 and subm. by W. Culican. Comment (W.C.): there is some possible stylistic connection between pottery associated with V-57 and that associated with $\mathrm{V}-56$.

\section{V-58. Ahar mound, Trench J}

$$
3890 \pm 100
$$

Charcoal from Layer 10, $41 \mathrm{ft}$ below datum; a level containing little pottery and lying immediately upon the shingle of an extinct river bank. Possibly represents earliest Chalcolithic occupation on the site. Coll. Feb 1962 and subm. by W. Culican.

\section{V-55. Ahar mound, Trench $K$}

$$
3825 \pm 120
$$

stratioraphically stratigraphically sealed sterile riverine clay and shingle layer, ca. $41 \mathrm{ft}$ 6 in. below datum. Mud impressions of bamboo sticks were found near sample. Coll. Jan 1962 by C. E. V. Nixon; subm. by W. Culican.

\section{CROSS-CHECK SAMPLES}

For dates published before 1961, allowance should be made for some variation due to the differences in laboratory reference standards and also, for the earliest published dates, for absence of Suess effect correction.

\section{V-3. Lake Nemi, Italy}

Average: $2110 \pm \mathbf{5 0}$ gula (A.D. 37 to 41) which were lying at bottom of Lake Nemi, Alban Hills, near Rome $\left(40^{\circ} 43^{\prime} \mathrm{N}\right.$ Lat, $12^{\circ} 42^{\prime} \mathrm{E}$ Long, these coordinates taken from Rome II). Part of material supplied to Hl. de Vries, Groningen. Dates obtained by other laboratories: $2030 \pm 200$ (Ballario et al., 1955); R-1, $2125 \pm 75$, average of 6 measurements (Bella and Cortesi, 1957); T-9, $1880 \pm 130$ (Nydal and Sigmond, 1957); St-103 A, $1940 \pm 70$, St-103 B, $2090 \pm 75$, av. $2010 \pm 65$ (Stockholm I); U-68, $1980 \pm 70$ (Uppsala I) to which should be added $135 \pm 35$ (Uppsala III); BM-15, $2080 \pm 150$ (British Museum I); Q-112, $1904 \pm 95$ (Cambridge I); R-1 remeasured, $1990 \pm 85$ (Rome II); U-239, $2120 \pm 80$ (Uppsala IV).

\section{V-3 B. \\ V-3 C.}

$$
\begin{aligned}
& 2075 \pm 70 \\
& 2145 \pm 70 \\
& 1170 \pm 70
\end{aligned}
$$

\section{V-28. St. Walburg church, Netherlands}

A.D. 780

Wood from St. Walburg church at Groningen, Netherlands (53 $12^{\prime}$ $\mathrm{N}$ Lat, $6^{\circ} 36^{\prime} \mathrm{E}$ Long. Groningen lab. obtained an average age of 1000 
yr based on nine measurements (de Vries and Barendsen, 1954; for correction see Groningen IV). Other results obtained include: C-621, $2222 \pm$ 200 (Libby, 1955); GL-23, $950 \pm 80$ (Zeuner, 1955); T-29, $1050 \pm 100$ (Nydal and Sigmond, 1957); H-8-7, $1245 \pm 130$ (Münnich, 1957); U-69, $1095 \pm 70$ (Uppsala I), to which should be added $135 \pm 35$ (Uppsala III); A-81 A/B, $900 \pm 160$ (Arizona II); L-292, $1250 \pm 150$ (Lamont V); K-143, $1380 \pm 120$ (Copenhagen III); A-81 bis, $1080 \pm 140$ (Arizona III); Hv-63, $1075 \pm 95$ (Hannover I).

V-31. Nabu Temple, Nimrud, Iraq

$2695 \pm 85$

745 B.c.

Charred wood from Nabu Temple at ancient Nimrud on E bank of Tigris, $22 \mathrm{mi} \mathrm{S}$ of modern Mosul (36 $11^{\prime} \mathrm{N}$ Lat, $43^{\circ} 20^{\prime} \mathrm{E}$ Long), Iraq. Coll. April 1962 by M. E. Mallowan, Univ. of London. Archaeological date of material should be some decades before 612 B.c. Sample has been dated by British Mus. lab. at $2400 \pm 150$ (BM-59, British Museum II) and by Dublin lab. at $2506 \pm 140$ (D-70, Dublin I). A second dating by Dublin lab., using NBS oxalic-acid standard, gave $2730 \pm 120$ (Dub$\operatorname{lin} \mathrm{I})$.

\section{V-29. Two Creeks, Wisconsin}

$11,660 \pm 135$ 9710 B.C.

Wood from Two Creeks forest bed (approx. $44^{\circ} 15^{\prime} \mathrm{N}$ Lat, 87 $34^{\prime}$ W Long); part of material dated by Arizona lab. (A-79). Age of forest bed, and dates obtained on materials from Two Creeks forest, are discussed by Broecker and Farrand (1963). Dates obtained by other laboratories: Y-141, $9929 \pm 406$ (Yale I); W-42, 11,350 $\pm 120, W-83,11,410 \pm$ 180 , av. $11,370 \pm 100$ (USGS I); Y-227, 11,130 \pm 350 (Yale II); Chicago, av. of 5 measurements, 11,404 \pm 350 (Libby, 1955); M-342, 10,700 \pm 600 , M-343, 10,400 \pm 600 (Michigan I); A-79 A, 12,150 4 400, A-79 B, 12,000 \pm 400 , av. 12,000 \pm 280 (Arizona II); W-670, 12,200 $\pm 400, W-698$, $11,550 \pm 300$ (USGS V); L-607 A, 11,850 \pm 100, (Broecker and Farrand, 1963).

V-30. Ruds Vedby, Denmark

$11,245 \pm 180$

9295 B.C.

Wood from thin layer representing pollen zone boundary II/III, Aller $\phi d$-Younger Dryas, at Ruds Vedby, Zealand, Denmark $\left(55^{\circ} 32^{\prime} \mathrm{N}\right.$ Lat, $11^{\circ} 22^{\prime}$ E Long). Dates obtained by other laboratories: K-101, av. 3 measurements, $10,890 \pm 240$ (Copenhagen I); W-82, 10,260 $\pm 200, \mathrm{~W}-84$, $10,510 \pm 180$, av. $10,400 \pm 160$ (USGS I); H-105-87, 11,500 \pm 300 (Münnich, 1957); St-18, 10,200 \pm 370 (Stockholm I) ; Gro-454, 10,995 \pm 250 (Groningen II, for correction see Groningen IV); U-20, 10,830 \pm 130 , U-75, 10,680 \pm 130 (Uppsala I), to which should be added $135 \pm 35$ (Uppsala III); BM-19, 11,333 \pm 200 (British Museum I); K-101 bis, recalculated, 11,090 \pm 240 (Copenhagen III); R-64, 11,900 \pm 170 (Rome II); R-64, remeasured, $11,200 \pm 145$ (Rome III); K-101, remeasured, $10,970 \pm 120$ (Copenhagen VI). 
Date lists:

Arizona II

Arizona III

British Museum I

British Museum II

Cambridge I

Copenhagen I

Copenhagen III

Copenhagen VI

Dublin I

Gakushuin III

Gakushuin IV

Groningen II

Groningen IV

Hannover I

Lamont V

Michigan I

New Zealand I-V

Rome II

Rome III

Stockholm I

Tata I

Uppsala I

Uppsala III

Uppsala IV

USGS I

USGS $\mathrm{V}$

Yale I

Yale II

Vale VIII

\section{REFERENCES}

Shutler and Damon, 1959

Damon and Long, 1962

Barker and Mackey, 1959

Barker and Mackey, 1960

Godwin and Willis, 1959

Anderson, Levi and Tauber, 1953

Tauber, 1960

Tauber, 1964

McAuley and Watts, 1961

Kigoshi, Lin and Endo, 1964

Kigoshi and Kobavashi, 1965

de Vries, Barendsen and Waterbolk, 1958

Vogel and Waterbolk, 1963

Wendt, Schneekloth and Budde, 1962

Olson and Broecker, 1959

Crane, 1956

Grant-Taylor and Rafter, 1963

Alessio, Bella and Cortesi, 1964

Alessio et al., 1965

Östlund, 1957

Kusumgar, Lal and Sarna, 1963

Olsson, 1959

Olsson et al., 1961

Olsson and Kilicci, 1964

Suess, 1954

Rubin and Alexander, 1960

Blau, Deevey, and Gross, 1953

Preston, Person and Deevey, 1955

Stuiver, Deevey and Rouse, 1963

Alessio, M., Bella, F., and Cortesi, C., 1964, University of Rome carbon-14 dates II: Radiocarbon, v. 6, p. 77-90.

Alessio, M., Bella, F., Bachechi, F., and Cortesi, C., 1965, University of Rome carbon-14 dates III: Radiocarbon, v. 7, p. 213-222.

Anderson, E. C., Levi, Hilde, and Tauber, H., 1953, Copenhagen natural radiocarbon measurements I: Science, v. 118, p. 6-9.

Ballario, C., Beneventano, M., Marco, A. de, Magistrelli, F., Cortesi, C., and Mantovani, T., 1955, Apparatus for carbon-14 dating: Science, v. 121, p. 409-412.

Barker, H., and Mackey, C. J., 1959, British Museum natural radiocarbon measurements I: Am. Jour. Sci. Radioc. Supp., v. 1, p. 81-86.

1960, British Museum natural radiocarbon measurements II: Am. Jour. Sci. Radioc. Supp., v. 2, p. 26-30.

Bella, F., and Cortesi, C., 1957, Attività del laboratorio dell'Università di Roma per le datazioni con il C.14: Ricerca Scientifica, v. 27, p. 2677-2680.

Blau, M., Deevey, E. S., and Gross, M. S., 1953, Yale natural radiocarbon measurements I. Pyramid Valley, New Zealand and its problems: Science, v. 118, p. 1-6.

Broccker, W. S., and Farrand, W. R., 1963, Radiocarbon age of the Two Creeks forest bed, Wisconsin: Geol. Soc. Am. Bull., v. 74, p. 795-802.

Butler, B. E., 1959, Periodic phenomena in landscapes as a basis for soil studies: Commonwealth Sci. and Industrial Res. Organization, Australia, Soil Pub. no. 14, $20 \mathrm{p}$.

Carman, R. D., 1961, Stabilization of the over-all counting sensitivity of gas-filled proportional counting system: Australian Jour. Sci., v. 23, p. 340-343.

Crane, H. R., 1956, University of Michigan radiocarbon dates I: Science, v. 124, p. $664-672$.

Culican, William, 1961-1962, Excavations at the Mound of Ahar (Rajasthan): AbrNahrain, v. 3, p. 75-89.

Damon, P. E., and Long, Austin, 1962, Arizona radiocarbon dates III: Radiocarbon, v. 4 , p. $239-249$

Focken, C. M., 1960, Radiocarbon dating laboratory, Museum of Applied Science of Victoria: Australian Jour. Sci., v. 23, p. 127. 
1962, Australia's first carbon-14 dating laboratory: Nature, v. 193, p. 420-421.

Godwin, H., and Willis, E. H., 1959, Cambridge University natural radiocarbon measurements I: Am. Jour. Sci. Radioc. Supp., v. 1, p. 63-75.

Grant-Taylor, T. L., and Rafter, T. A., 1963, New Zealand natural radiocarbon measurements I-V: Radiocarbon, v. 5, p. 118-162.

Hale, H. M., and Tindale, N. B., 1930, Notes on some human remains in the lower Murray Valley, South Australia: Recs. S. Australian Mus., v. 4, p. 145-218.

Kigoshi, K., Lin, D.-H., and Endo, K., 1964, Gakushuin natural radiocarbon measurements III: Radiocarbon, v. 6, p. 197-207.

Kigoshi, K., and Kobayashi, H., 1965, Gakushuin natural radiocarbon measurements IV: Radiocarbon, v. 7, p. 10-23.

Kusumgar, S., Lal, D., and Sarna, R. P., 1963, Tata Institute radiocarbon date list I: Radiocarbon, v. 5, p. 273-282.

Lal, B. B., 1962-1963, A picture emerges: an assessment of the carbon-14 datings of the protohistoric cultures of the Indo-Pakistan subcontinent: Ancient India, no. 18-19, p. 214.

Langford-Smith, Trevor, 1960, The dead river systems of the Murrumbidgee: Geog. Rev., v. 50, p. 368-389.

1962, Riverine plains geochronology: Australian Jour. Sci., v. 25, p. $96-97$

Libby, W. F., 1955, Radiocarbon dating, 2d ed.: Chicago, Univ. Chicago Press, ix, 175 p.

McAuley, I. R., and Watts, W. A., 1961, Dublin radiocarbon dates I: Radiocarbon, v. 3 , p. 26-38.

McBryde, I., 1961, New radiocarbon dates for Australia: Antiquity, v. 35, p. 312-313. 1962, Archaeological field survey work in northern New South Wales: Oceania, v. 33, p. $12-17$.

1963, Archaeology in New England: Armidale, Univ. New England, New England Essays, p. 63-74.

1965, Radiocarbon dates for archacological sites in the Clarence Valley, northern New South Wales: Oceania, v. 35, p. 260-266.

McCarthy, F. D., 1948, The Lapstone Creek excavation: two culture periods revealed in eastern New South Wales: Recs. Australian Mus., v. 22, p. 1-34.

1949, The prehistoric cultures of Australia: Oceania, v. 19, p. 305-319. p. $177-190$

1961, Report on Australia and Melanesia: Asian Perspectives, v. 5, p. $141-155$.

1963, The prehistory of the Australian aborigines: Australian Nat. History, v. 14 , p. $233-240$.

1964, The archacology of the Capertee Valley, New South Wales: Recs. Australian Mus., v. 26, p. 197-246.

McCarthy, F. D., and Setzler, F. M., 1960, The archaeology of Arnhem Land: Recs American-Australian Scientific Expedition to Arnhem Land, 2, Melbourne, Melbourne Univ. Press, p. 215-295.

Megaw, J. V. S., 1965, Excavations in the Royal National Park: Oceania, r. 35, p. 202-207.

Mulvaney, D. J., 1960, Archaeological excavations at Fromm's Landing on the lower Murray River, South Australia: Proc. Royal Soc. Victoria, v. 72, p. 53-85.

1961, The stone age of Australia: Proc. Prehistoric Soc., v. 27, p. 56-107.

Münnich, K. O., 1957, Heidelberg natural radiocarbon measurements I: Science, v. 126 , p. 194-199.

Nydal, Reider, and Sigmond, R. S., 1957, Radiocarbon dating in Trondheim: Appl. Sci. Res., sec. B, v. 6, p. 393-400.

Olson, E. A., and Broecker, W. S., 1959, Lamont natural radiocarbon measurements V: Am. Jour. Sci. Radioc. Supp., v. 1, p. 1-28.

Olsson, Ingrid, 1959, Uppsala natural radiocarbon measurements I: Am. Jour. Sci. Radioc. Supp., v. 1, p. 87-102.

Olsson, I., Cazeneuve, H., Gustavsson, J., and Karlén, I., 1961, Uppsala natural radiocarbon measurements III: Radiocarbon, v. 3, p. 81-85.

Olsson, I. U., and Kilicci, S., 1964, Uppsala natural radiocarbon measurements IV: Radiocarbon, v, 6, p. 291-307.

Östlund, H. G., 1957, Stockholm natural radiocarbon measurements I: Science, v. 126, p. $493-497$. 
Preston, R. S., Person, Elaine, and Deevey, E. S., 1955, Yale natural radiocarbon measurements II: Science, v. 122, p. 954-960.

Rao, S. R., 1959-60, Indian archaeology-a review: Archaeol. Survey of India.

Rubin, M., and Alexander, C., 1960, U.S. Geological Survey radiocarbon dates V: Am. Jour. Sci. Radioc. Supp., v. 2, p. 129-185.

Sankalia, H. D., 1961-1962, Excavation at Ahar, District Udaipur: Indian Archaeology, p. $45-50$

1962, Indian Archaeology Today: Bombay, Asia Publishing House, 144 p.

Shutler, Dick Jr., and Damon, P. E., 1959, University of Arizona radiocarbon dates II: Am. Jour. Sci. Radioc. Supp., v. 1, p. 59-62.

Stuiver, Minze, Deevey, E. S., and Rouse, Irving, 1963, Yale natural radiocarbon measurements VIII: Radiocarbon, v. 5, p. 312-341.

Suess, H. E., 1954, U.S. Geological Survey radiocarbon dates I: Science, v. 120 , p. $467-473$.

Tauber, Henrik, 1960, Copenhagen natural radiocarbon measurements III, corrections to radiocarbon dates made with the solid carbon technique: Am. Jour. Sci. Radioc. Supp., v. 2, p. 5-11.

1964, Copenhagen radiocarbon dates VI: Radiocarbon, v. 6, p. 215-225.

Thompson, B. R., 1965, Groundwater investigation of the Ovens and King Valley: Victoria, Mines Department, unpublished rept.

Tindale, N. B., 1957, Culture succession in south eastern Australia from late Pleistocene to the present: Recs. S. Australian Mus., v. 13, p. 1-49.

1961, Archaeological excavation of Noola rock shelter: a preliminary report: Recs. S. Australian Mus., v. 14, p. 193-196.

Vogel, J. C., and Waterbolk, H. T., 1963, Groningen radiocarbon dates IV: Radiocarbon, v. 5, p. 163-202.

Vries, Hl. de, and Barendsen, G. W., 1954, Measurements of age by the carbon-14 technique: Nature, v. 174, p. 1138-1141.

Vries, Hl. de, Barendsen, G. W., Waterbolk, H. T., 1958, Groningen radiocarbon dates II: Science, v. 127, p. 129-137.

Walker, P. H., 1962, Terrace chronology and soil formation on the south coast of N.S.W.: Jour. Soil Sci., v. 13, p. 178-186.

Warner, W. F., 1937, A Black Civilization, 2d ed: New York, Harper and Brothers, $\mathrm{xx}, 618 \mathrm{p}$.

Wendt, I., Schneekloth, H., and Budde, E., 1962, Hannover radiocarbon measurements I: Radiocarbon, v. 4, p. 100-108.

Williamson, W. H., 1961, Cainozoic geology of Lachlan Valley, N.S.W.: A.N.Z.A.A.S. Congress, 35th, Brisbane, Australia, 29 May to 2 June, 1961, Sec. C, unpub. rept. Congress, 1964 , The development of ground-water resources of alluvial formations: Symposium Australian Acad. Sci., Canberra, Australia, 9-13 Sept 1963, Water Resources Use and Management, Melbourne, Melbourne Univ. Press, p. 195-211. Zeuner, F. E., 1955, Radiocarbon dates: Univ. London Inst. Archaeology 11th Ann. Rept., p. 43-50. 